\title{
The Challenges of Bumiputera Furniture SME in Design Capabilities.
}

\author{
Nur Syazana Osman, ${ }^{1,2}$, Khairul Aidil Azlin Abd. Rahman ${ }^{1}$, Ahmad Rizal Abdul Rahman ${ }^{1}$, Mohamad Fakri \\ Zaky Ja'afarl \\ ${ }^{1}$ Department of Industrial Design, Faculty of Design and Architecture, Universiti Putra \\ Malaysia \\ ${ }^{2}$ Universiti Kuala Lumpur, Malaysia Italy Design Institute
}

\begin{abstract}
In the furniture industry in Malaysia, the factors that influence the export value of Bumiputera furniture SME manufacturers have already been discussed, and with the lack of clusters that could continue the survival of Bumiputera manufacturers in this industry is getting worse. Although the furniture sector has the highest export value, the participation of Bumiputera furniture SME is very low compared to others. This is disrupted as the current Bumiputera furniture SME is incapable, due to the increasing competition or weakness in different aspects of entrepreneurship and other factors, to continue the business sustainability. This article aims to discuss the design capabilities that affect the performance of Bumiputera furniture SME manufacturers and how to overcome through strategic design approaches. In this study, a set of questionnaire was distributed to 30 companies and analyzed using the IBM Social Sciences Statistical Package (SPSS) to test the reliability. The further analysis was the use of frequency analysis and principal component analysis (PCA). The results have important implication for the future direction of research to improve organizational performance of Bumiputera furniture SME manufacturers.
\end{abstract}

Key words: Bumiputera, SME Furniture Manufacturers, Furniture Industry, Business Performance,

\section{INTRODUCTION}

Since the implementation of the New Economic Policy (NEP) in 1971, government development programs have focused on achieving national unity in a multi-racial society through an integrated approach to eradicating poverty. One of the main strategic thrusts of the NEP is the development of Bumiputera entrepreneur on the agenda for the establishment of the Commercial and Industrial Community (BCIC). The main objective of the $\mathrm{BCIC}$ is to increase the participation of Bumiputera entrepreneurs in competitive and sustainable trade and industry activities at both domestic and international level. In earlier years, when the total export of wood and wood products in 1997 amounted to some RM14.72 billion and the share of furniture was 17.7 per cent, the total contribution made by the Bumiputera entrepreneurs to the export of furniture was 4.5 per cent, which was also the peak contribution made by the Bumiputera. This sector exhibited a decreasing trend between early 2001 and 0.3 percent between 1997 and 2007 [1]. However, the overall success of the development programs for Bumiputera has failed to meet expectations.
This is reflected in Bumiputera export business performance compared to its national results. The exporters from Bumiputera have contributed RM28 million or 0.4 percent and remain in 2008 until 2014. Furniture exports totalized RM7 billion. The overall export value of Bumiputera entrepreneurs in the following years has increased by 1.78 percent, but trends have decreased in 2016 to less than 1 percent in 2017 [2]. A few reasons can be attributed to the lack of performance among Bumiputera furniture SME [3][2]:

a. Limited capacity to meet the challenges of market liberalization and globalization

b. Limited technology management and knowledge acquisition capacity

c. Low productivity and quality input

d. Shortage of skills for new business environment

e. Limited access to finance and capital and the infancy of venture funds in initial or mezzanine funding

f. High infrastructure costs: the majority of SMEs are still located on land not intended for industrial use

g. Lack of knowledge and access to information

Corresponding Author: Nur Syazana Osman, Department of Industrial Design, Faculty of Design and Architecture, Universiti Putra Malaysia, email: nursyazana@unikl.edu.my, H/P: +6018 3665395 
Despite overall development programs do not meet expectations, the government continues to encourage SME participation in Bumiputera furniture at all levels. In order to better prepare for long-term and competitively in this industry, government emphasis is given to guiding entrepreneurs among Bumiputera through a variety of programs like entrepreneurship, business skills and marketing and promotion. The government has also provided the Bumiputera entrepreneur with the consolidation of an integrated timber complex, including lodging, manufacturing and marketing activities, the restructuring of industrial furnishings parks, the creation of central purchasing facilities, and active participation in R\&D activities aimed at improving the product.

Unfortunately, these objectives will not succeed, as Bumiputera manufacturers are unable to integrate design elements [4] into their business and create a climate that will enable the industry to enter the next phase of growth. Below are the main issues of Bumiputera furniture manufacturers SMEs:

\section{a. Lack of incorporate design in organization}

Innovative and design elements among Bumiputera furniture SME are considered weak and immature in South East Asia [5] [6]. Bumiputera manufacturers tend to copy other designs and apparently lack product development [7] and this affect the product quality [8]. Besides that, they also lack of experience in introducing new ideas into production leads to a decline in the production segment, and manufacturers are unable to compete in the low-end market segment. As a result, the creativity in an organisation, which is an essential source of competitive advantage, is not encouraged.

\section{b. Lack of strategic design management}

By implementing creative [9] strategies for local manufacturers products or services in order to improve organization performance and sustainable competitive benefits, the government has formulated aggressive strategies for this sector. However, some of the strategies that are implemented are not as successful as expected and Bumiputera manufacturers have lost their competitiveness in this industry. The main problem faced by Bumiputera furniture manufacturers is lack of expertise in design management based on findings. Meanwhile, Mamat and Ismail [10] pointed out that Bumiputera manufacturers also lack financial management, human resource management and marketing management.

c. Low awareness in brand management practice
Since the government is pursuing local manufacturers to adopt a brand strategy for their organization, this has caused manufacturers refuse to innovate and are more interested in export marketing than branding [10]. They focus more on increasing sales with minimal design costs and are largely insufficient to meet the challenges of the global market due to their limited knowledge and awareness of the importance of branding to organizational performance [11].

\section{METHODOLOGY}

The interview and questionnaire survey were used to gain the data in this study. The in-depth interview $(n=6)$ was conducted between manufacturing experts and professional designers. The interview was carried out over a period of time and the interview was guided by a structured interview. While the questionnaire survey was distributed among the Bumiputera furniture SME manufacturers $(n=30)$. The respondent involved in this survey is the general manager / CEO or the person in charge of the company's product design.

Based on the literature review, the scale used in this study is Likert Scale (5- point scale: 1- strongly disagree with 5- strongly agree). The results of median parameters show excellence between 4 and 5, fairness between 3.5 and 3.9 andlow performance between 3.0 and 3.49. Then, the data collected from the survey were compiled. At this stage, in the excel software, the data collected through the questionnaire survey were coded and transformed into matrix form. This allows the data to be analyzed using statistical software packages such as IBM SPSS. Data analysis for the quantitative method has been undertaken in various stages: data preparation and screening, descriptive statistics, main component analysis (PCA), scale reliability analysis and hierarchical cluster analysis.

\section{RESULT ANALYSIS AND DISCUSSIONS}

In Part Two of the questionnaire, this study identified items or variables from the literature that are believed to have affected the business growth of Bumiputera furniture SME. Table 1.1 shows the descriptive statistics in terms of mean and standard deviation for each competitive factor measure. The mean ranged from 3.10 to 4.53 on a scale of 1 to 5 , with 5 being the highest measure of each variable. The results show that there are several factors that have led to the unsuccessful of Bumiputera furniture SME in the industry and need action from Bumiputera manufacturers to improve their design capabilities that impact the organization's internal and external performance. 
Nur Syazana Osman et al./ International Journal of Business and Management, 3(2) 2019, Pages: 21-25

Table 1.1 : Factors that have led to the unsuccessful of Bumiputera furniture SME

\begin{tabular}{|c|c|c|}
\hline & & Mean \\
\hline 1 & Design & 3.95 \\
\hline 2 & Human capital development & 3.67 \\
\hline 3 & Production & 3.5 \\
\hline 4 & IPR & 3.4 \\
\hline 5 & Strategic management & 3.35 \\
\hline 6 & Investment & 3.03 \\
\hline
\end{tabular}

Table 1.1, shows that Bumiputera manufacturers lack in production, intellectual property rights, strategic management and investment in design activities. In the context of Bumiputera, only a few producers of similar technology are able to operate enough modern equipment among the technologylevel manufacturers in other industries. This is due to the lack of investment capital to improve technology. Most Bumiputera manufacturers only have the technology to fulfill domestic market demands in basic production activities but are insufficient for export processing. As a consequence, the processing capacity is limited, and due to its limited processing capacity it is not visible on the export market. In addition, the manufacturers of Bumiputera face difficulties in surviving in this industry due to the weakness of management skills. This affects the organization's management performance and decision-making

\section{Principal Component Analysis (PCA)}

This study also conducted a Principal Component Anlysis (PCA), to determine the similarities between the variables (Table 1.2). The goal is to reduce a larger set of variables into a smaller artificial set that takes into account most of the variables in the original.

Table 1. 2: Rotated component matrix

\begin{tabular}{|c|c|c|c|c|}
\hline & 1 & 2 & 3 & 4 \\
\hline Product attractiveness & 0.927 & & & \\
\hline Driven innovation & 0.916 & & & \\
\hline Product aesthetic & 0.909 & & & \\
\hline Producing a good product & 0.886 & & & \\
\hline Strategic tools & 0.872 & & & \\
\hline Product development & 0.823 & & & \\
\hline $\begin{array}{l}\text { Employee are encouraged to take calculated } \\
\text { risk with new idea }\end{array}$ & 0.792 & & & \\
\hline $\begin{array}{l}\text { The skills, knowledge and decision making } \\
\text { of designers }\end{array}$ & 0.73 & & & \\
\hline Profitability & 0.703 & 0.402 & & \\
\hline Creative process & 0.659 & 0.521 & & \\
\hline Expertise in product design department & 0.649 & 0.602 & & \\
\hline Expertise in marketing department & 0.63 & 0.615 & & \\
\hline Customer satisfaction & 0.547 & & 0.431 & \\
\hline Competitiveness & 0.477 & 0.442 & & \\
\hline Company sustainability & & 0.766 & & \\
\hline Market segmentation & & 0.727 & & \\
\hline Expertise in management department & & 0.707 & 0.423 & \\
\hline $\begin{array}{l}\text { Recruitment, compensation, reward and } \\
\text { training policies }\end{array}$ & & 0.704 & & \\
\hline Market demand & 0.427 & 0.67 & & \\
\hline Marketing communication & 0.492 & 0.617 & & \\
\hline Design process & 0.422 & 0.51 & & \\
\hline Licensing revenues & & & 0.846 & \\
\hline Entry new market & & & 0.793 & \\
\hline Blocking competitors & & & 0.775 & \\
\hline Protecting company trademark & & & 0.552 & \\
\hline Brand loyalty & 0.46 & & 0.495 & \\
\hline $\begin{array}{l}\text { Formal training to develop skills and } \\
\text { knowledge }\end{array}$ & & 0.425 & 0.47 & \\
\hline Preventing copying & & & & \\
\hline Design focused operation & & & & 0.823 \\
\hline Manufacturing performance & -0.469 & & & 0.746 \\
\hline Corporate culture & & & & 0.73 \\
\hline Customer driven manufacturing & & & & 0.707 \\
\hline Manufacturing knowledge & & & & 0.706 \\
\hline $\begin{array}{l}\text { Extraction Method: Principal Component } \\
\text { Analysis. }\end{array}$ & & & & \\
\hline Cronbach's Alpha & 0.952 & 0.937 & 0.838 & 0.775 \\
\hline
\end{tabular}

The four components with 32 variance variables were obtained in the PCA. Furthermore, for each component in Cronbach, the result is greater than 0.7 . In general, $>0.7$ or $>0.8$ is considered reliable for Cronbach's Alpha (Field, Miles, Filed, 2013) and all factors extracted during the preceding factor analysis have been reliably analyzed. 


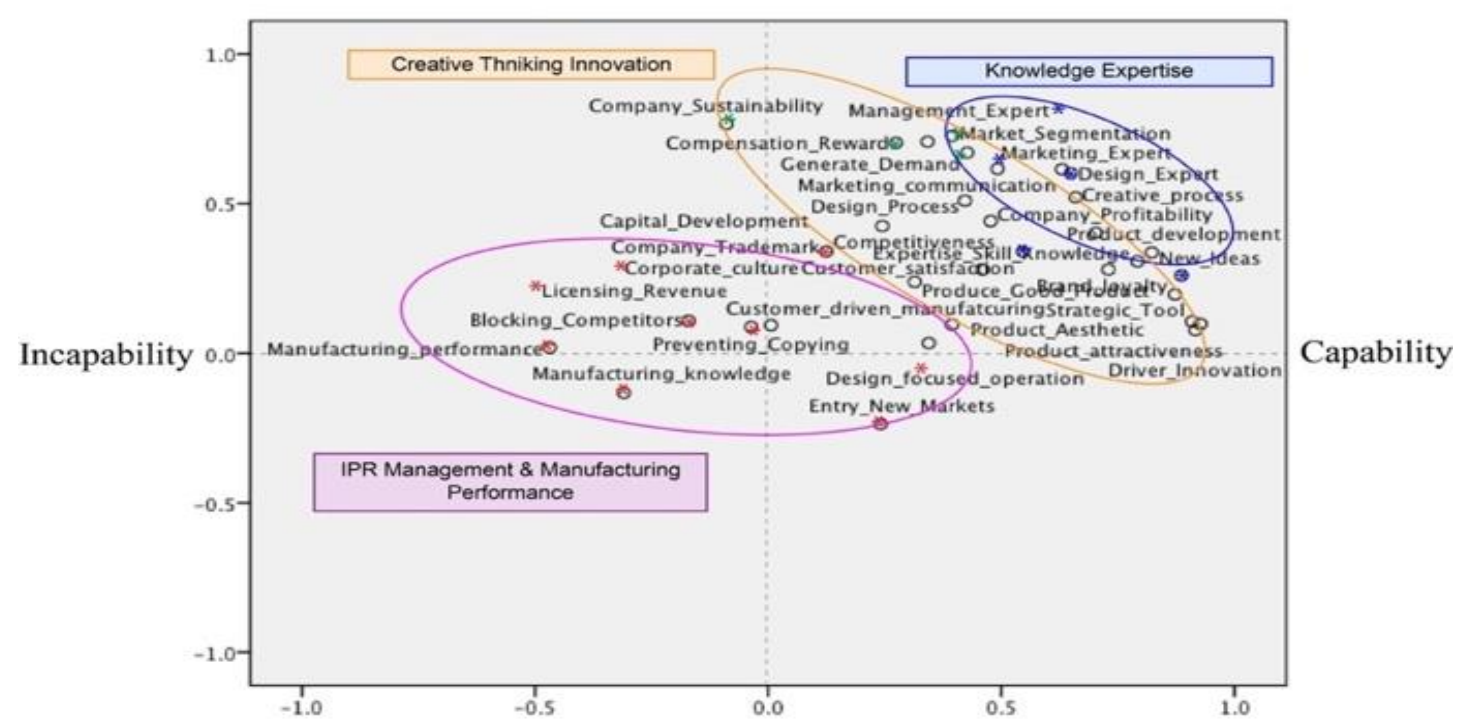

Figure 1. 1: Three cluster found from Ward Linkage method

Figure 1.1 shows the projecting matrix for the organizational capacity of Bumiputera SME manufacturers in the furniture industry in Malaysia. Three clusters were derived from this analysis and three meaningful subgroups were detected; (i) performance in IP management and manufacturing, (ii) knowledge of expertise, and (iii) innovation in creative thinking.

\section{i) IP Management and Manufacturing Performance}

The conclusions show that most Bumiputera furniture SMEs are unable in the absence of capital investment to improve operational performance. This hinders the manufacturer's ability to modernize its operating technology, like machinery and production agility. The Bumiputera furniture SME wish to increase their levels of productivity, as they understand and know that advanced technology contributes not only to a high quality of the products, but also to material waste reduction, production costs, and the reduction of foreign workers. However, only $20 \%$ of the companies had used certain automation in the production process and $80 \%$ had basic machinery.

From this result, it shows that high capital investment and high maintenance costs are essential for the implementation of advanced technology, followed by the incompatibility of technology and poor technology literacy among employees. This has therefore affected R\&D development of new products, which often involves high infrastructural costs and manual power costs. This has made it difficult for manufacturers to enter new markets and, as a result of productivity constraints, they are unable to meet market demand. ii) Expertise knowledge

Bumiputera furniture SME look forward to knowledge at all levels of the organization: (i) design expertise, (ii) marketing experience, and (iii) management expertise. Bumiputera manufacturers see human capital development as a key component of their business unit and corporate strategies and aim for talent development to be successful.

Bumiputera manufacturers really need to use the workforce as a competitive weapon to develop a competitive advantage. By optimizing their workforce through the competitive development of human capital, sustainable development will not only achieve business goals, but above all long-term survival. In order to accomplish this undertaking, Bumiputera manufacturers need to invest in resources to ensure that employees have the knowledge, skills and competencies to work effectively in a rapidly changing and complex environment. Most respondents viewed the development of human capital as having a good competitive advantage to enhance higher performance.

\section{iii) Creative thinking innovation}

The design of the manufacturers in today's furniture industry needs to be adapted because it is an important part of ensuring company success and sustainability. Bumiputera furniture SMEs need to improve their capacity to develop new products by offering value-added product appeal, aesthetics and innovation as a strategic tool in both value and strategic terms. By being the source of good marketing strategy, processes and brand values. In addition, to create creative thinking and generate 
Nur Syazana Osman et al./ International Journal of Business and Management, 3(2) 2019, Pages: 21-25

creative ideas among employees, Bumiputera furniture SMEs also need to adapt the use of creative processes in their companies. It will also assist manufacturers in problem solving and for a successful marketing with the involvement of designers or expertise in design and decision making. This ensures product marketing success in the markets.

\section{CONCLUSIONS}

This study found that Bumiputera furniture SME face several transition challenges that affect them to remain competitive in this industry, where it requires Bumiputera manufacturers to increase their design capabilities in three main comprehensive areas; (i) performance in IP management and manufacturing, (ii) knowledge of expertise, and (iii) innovation in creative thinking. It is commonly important for Bumiputera manufacturers to enhance their design capabilities to ensure the successful transition from OEM to ODM / OBM. Moreover, Bumiputera manufacturers need to strengthen their internal capacity through a cross-broader strategic alliance to strengthen new product development, and not only improve their operational productivity, but also create a new value proposition and enhance business strategy through design.

\section{ACKNOWLEDGMENTS}

The authors would like to thank the following individuals for their fruitful debates. My peers and the anonymous audience from the prior meeting are grateful for their precious remarks and thoughts on the paper's presentation, which is a contribution to the study's contextualisation strategy. This research is sponsored in part by UPM Grant Scheme reference no GP-IPS/2018/9617700.

\section{REFERENCES}

[1] Fadzline Tamyez, P., Razali, A., \& Norzanah, M. (2008). The Dilemma of Bumiputera Furniture Entrepreneurs. 2008ifcx International Furniture Conference and Exhibition.

[2] Osman, N. S., Rahman, K. A. A. A., Rahman, A. R. A., \& Ja'afar, M. F. Z. (2018a). Competitive Influence Factors among Bumiputera Furniture Manufacturer. International Journal of Academic Research in Business and Social Sciences, 8(7), 445452. http://doi.org/10.6007/IJARBSS/v8i7/4386
[3] Mohidin, M. J. (2002). An Analysis On Competitiveness of STIDC Vendor Companies. Universiti Malaysia Sarawak.

[4] Osman, N. S., Rahman, K. A. A. A., Rahman, A. R. A., \& Ja'afar, M. F. Z. (2018b). The Effect of Design Capability Characteristic on Design Performance for Bumiputera Furniture Companies. International Journal of Business and Management, 2(3), 30-35. http://doi.org/10.26666/rmp.ijbm.2018.3.5

[5] Ratnasingam, J., \& Ioras, F. (2003). The sustainability of the Asian wooden furniture industry. European Journal of Wood and Wood Products, 61, 233-237. http://doi.org/10.1007/s00107-003-0382-9

[6] Nor, N. M., Fadzline Tamyez, P., Jamal, S., \& Nasir, A. (2012). A Conceptual Framework on the Relationship between Furniture Design and Branding Strategy-Performance Relationship in Malaysian Exporting Furniture Firms. Online Journal of Social Sciences Research (02012 Online Research Journals Full Length Research, 1(2), 42-48. Retrieved from http://www.onlineresearchjournals.org/JSS

[7] Mohamed, S., \& Abdullah, S. (2006). Wooden Household Furniture: Does Brand Matter? Pertanika Journal of Tropical Agricultural Science, 29(1\&2), 19-14.

[8] Com, R., Da, O. C., Da, D., \& Produtos, I. D. E. (2017). Ceasing Copycat Behaviour: Developing Product-Design Identity Through Industry and Handcraft Interaction, 12(2), 2140.

[9] Acklin, C. (2011). Design Management Absorption Model - A Framework to Describe the Absorption Process of Design Knowledge by SMEs with Little or No Prior Design Experience. Proceedings of the Academic Design Management Conference, 22(September), 1-14. http://doi.org/10.1111/caim.12022

[10] Mamat, M., \& Ismail, A. (2011). The Study of Bumiputera Furniture Industry in Kelantan. American International Journal of Contemporary Research, 1(3), 88-98.

[11] Nor, N. M., Jamal, S., \& Fadzline, P. (2012). Brand Strategy in Small and Medium Size Enterprises (SMEs) In The Context Of The Malaysian Furniture Industry: Open-Ended. In Proceedings for the First International Qualitative Research Conference, (pp. 6-7). 